\title{
SHAKESPEARE IN THE 1980s
}

\author{
Margarida Gandara Rauen
}

\section{RESUMO}

Esta revisão, além de descrever as caracteristicas e implicações gerais da produção e da crítica Shakespeareanas da última década, identifica a controvérsia sobre prá. ticas editoriais como a mais marcante da época e considera alguns efeitos das novas tendèncias para o ensino.

What Shakespearean studies and production have reflected in the 1980s is what has happened in most areas of human knowledge during the decade: an expansion of methodological boundaries, a transformation of earlier fields. In many cases, we have also revived ideas essentially old but which we took years to perceive as important: perhaps because their generators were not "persons of their time", perhaps because we truly lacked information to explore and develop such ideas when they first appeared.

Appraisals of recent scholarship (e.g., Drakakis; Elam; Furness \& Ziegler) $^{1}$ and the annotated world bibliography published annually by the Folger Shakespeare Library (Washington, D.C., USA) indicate, above all, that Shakespeare is alive throughout the globe, be it in print or on cinema, television, and stage.

As Berkowitz suggests, the 1988 Edinburgh Shakespeare Festival (Scotland) was an example of such activity, including, in addition to the many professional and amateur productions, "another fourteen staged readings, parodies, and Shakespeare-inspired plays ... in venues as various as church halls, meeting rooms, school gyms, discos, and even real

1 DRAKAKIS, J., ed. Alternative Shakespeares. London, Methuen, 1985, ELAM, K. ed. Shakespeare today: directions and methods of research. Firenze: La Cass Usher. 1984. FURNEss, H. H.; \& ZIEGLER, G., ed. Shakespeare study today. New York: AMS Press. 1986. 
theatres."2 In the United States we find much polemic scholarship in progress and various Shakespeare Festivals, such as the ones in Colorado, Oregon, Louisiana, and New Jersey. The bulk od Shakespeare studies, translations and production in Germany, China, and Japan or even the scant but subsisting endeavours in Brasil and other Latin countries must also be mentioned.

This article will, as a state-of-the-art survey, focus only on the most revealing tendencies in Anglo-American theater production, scholarship, and criticism during the 1980 s.

\section{PRODUCTIONS: UPDATING, THE APOCHRYPHAL PLAYS, ORIGINAL PLAYTEXTS}

The average lay person and many critics still tend to view the Bard of Avon as a sacred figure, and his drama as a mirror of Elizabethan culture with definitive meanings. The truth, however, is that a popularization or quasi-demythification of Shakespeare becomes more and more apparent. The experimental nature of contemporary productions is an evidence of this era of freedom, of emancipation from conventional approaches.

Increasingly common is the trend of updating the plays through modern dress, music and props, a concept which dates back to the 1920s and director Barry Jackson. The original purpose was to bring the plays closer to the experience of the audience at a time when recreated Elizabethan conditions were dominant. Positive audience response is probably what makes updated interpretation more appealing nowadays. Updating, in addition, accentuates the universality and timelessness of Shakespeare's social and political themes and is a manifestation of Bertolt Brecht's (1898-1956) continuing Marxist influence on twentieth-century drama.

What follows is a description of a few updated productions recently done in Canada (Stratford-Ontario), England (London and Stratford-upon-Avon), and Scotland (Edinburgh), where we find some of the busiest Shakespeare theater.

Director Michael Bogdanov's Measure for Measure (Stratford Shakespeare Festival, Ontario, 1985) exploited a modern setting to accentuate the timelessness of moral absolutes and ironies in regard to sex and corruption. Bogdanov's conceit was clear as one entered the Festival Stage

2 BFRKowITZ. G.M. Shakespare it the 1988 Edinburgh Festival. Shakespeare Quarterly v. 40: D. 76, 1989. 
and immediately felt "in" the set, a smoky bar where transvestites and low life figures wearing leather and gangster costumes drank and talked to sensual contemporary music: thus, the "palace" of Duke Vincentio (where I, i is set) and Mistress Overdone's brothel were placed on the same footing.

The 1987 Season in Stratford, Ontario, featured two other memorable updated productions: Peter Moss's Much Ado about Nothing and David William's Troilus and Cressida. A Victorian setting for Much Ado provided an interesting context for the examination of the role of women in a maledominated society not too far removed from our own era. Troilus and Cressida was a vigorous social satire, with the Trojans wearing either Western clothing or East Indian dres, while the Greek commanders wore twentieth-century military uniforms. Visual references such as a transvestite party in III.iii and the recurrent bawdiness in stage-business implied that Helen corrupted Troy, which became a decadent society obsessed with sensuality and unable to oppose the Greeks. As Watermeier remarks, William's production, despite the "insightful choices that compelled attention to ... this complex play against the field of our own... complex times," spurred much "controversy and was variously condemmed as a shocking, confusing, radical distortion of Shakespeare's play."3

Michael Bogdanov's Romeo and Juliet (Royal Shakespeare Company, London, 1987), included disco dances, leather jackes, a red Alfa-Romeo convertible, motorbikes and sunglasses. As Berkowitz notes, "what worked best was the sense of rich and pampered young people driven to decadence and feuding by boredom":

Also Michael Bogdanov's was the trilogy 1 \& 2 Henry IV and Henry V, with First World War props, sounds of air support and costume design including various nineteenth and twentieth-century periods (English Shakespeare Company, London, 1986-87). Emerging from this contrast. were man's recurrent mistakes in his pathetic and everlasting quest for power through violence. The English Shakespeare Company has since then been on an international tour presenting the full cycle of The Wars of the Roses, which I am tempted to single out as the most ambitious updated approach to the histories ever. Not just because it requires

\footnotetext{
3 WATERMEIER. D. J. Shakespeare in Canada: the 1887 Stra:ford Festipal. Shakespcare Quarterly, y. 39: p. 229, 1988. BERKowITz. G. M. Slinkespeare in London. January-July 1987. Shakespeare
Quarterly, .. jS. p. 497, 1987.
} 
more than twenty hours of performance, but because director Bogdanov manages, as Jackson remarks, to ransack "the whole twentieth century and much of the nineteenth for parallels to the era of war, political intrigue, and civil unrest in which Shakespeare's histories are set".

Di Trevis's Much Ado About Nothing (Royal Shakespeare Company, Stratford-upon-Avon, 1988) also exploited a modern setting to present a "decadent, selfish, and profoundly unlikeable" society (Smallwood).6 Deborah Werner's costumes for ,King John (Royal Shakespeare Company, Stratford-upon-Avon, 1988) were "eclectic and anachronistic ... The cynical examination of political self-seeking ... cannot, the director suggests, be confined to a specific period" (Smallwood) ${ }^{i}$. Warner mixes first- and second-World War, medieval, Elizabethan and modern dress.

The Shanghai Kunju Theatre Macbeth, adapted by Zheng Shifeng and directed by $\mathrm{Li}$ Jia Yao (Edinburgh, 1987) stands out as a production with "... the sensibilities of another culture, ... demonstrating the universality of Shakespeare and of the art of Kunju theatre" (Weiss) ${ }^{8}$ Chinese costumes and energetic nonverbal representations of ambition, violence and grief added to the visual grandeur of Li's staging.

According to Berkowitz, the majority of the thirteen productions at the 1988 Edinburgh Festival featured updating. ${ }^{9}$ Particularly remarkable appears to have been director's Yukio Ninagawa's The Tempest (The Ninagawa Theatre Company), mixing Eastern and Western sytles: Japanese sounds and Western orchestral themes, Noh figures or geisha ritual and visible offstage action in the Brechtian manner, deeply contrasting yet resembling cultures. Maggi Law's staging of The Comedy of Errors (Able Bodies Company) was Turkish style, while Lisa Goldman's Twelfth Night (Cambridge Touring Theatre) was done as Miami Vice, including pastel suits, machine-gun-toting and cocaine-sniffing!

The above examples illustrate the range of updated approaches to Shakespeare. My selection may suggest that this style of production is widely accepted and appreciated these days, or that it has no shortcomings. Both assumptions would be false. While some contemporary criticism appears to accept updating as a legitimate way of re-

JACKBON. MacD. P. The Wars of the Roses, the English Shakespeare Company on tour. Shakespeare Quartely v. 39, p. 208, 1989.

6 SMALLWOOD, R. Shakcspeare at Stratford-upon-Aron. 1983. Shakespeare Quarterly v. 40, D. 84, 1989 .

SMALLWOOD, p. 92

WEISs. A. The Edinburgh Feztiva!. 1987. Shakespeare Quarterly v. 39, p. 85, 1988. BERKCWITZ (1989). 
creating Shakespeare, conservative stagings are still ruling, and far from losing their appeal. Overall, updating can bring intense energy and an innovative psychology to the plays, besides sharpening the audience's awareness of both plot and themes. But it may also come across as pointless, distracting and confusing, especially if the director's exploration of anachronism is gratuitous, with choices that have a visual impact but fail to signal thematic and dramatic relationships.

Two other "free" trends of the 1980 s, although not nearly as common as updating, are an interest in the apocryphal plays, and the use of quarto and folio playtexts, rather than only modern, conflated editions.

As Stodder points out, Shakespeare's apocrypha has been the focus of The Shakespeare Society of America's Globe Playhouse (Los Angeles, U.S.A.), with productions of The Two Noble Kinsmen, Sir Thomas More, Arden of Feversham, The Puritan, The Raigne of Edward III, The London Prodigal, and The Yorksire Tragedy, amongst others. ${ }^{10}$ The extent to which the realization of these plays in production reveals a Shakespearean style is an interesting question, and one which may pose challenges to language-focused discussions about authorship in the near future.

As for folio exploration, Director Jim Edmondson apparently achived, for example, a "provocative final view of Seyton" (Dessen) ${ }^{11}$ in his Macbeth (Oregon Shakespeare Festival, U.S.A.) by using the Folio pronunciation (Satan), rather than the orthodox one in modern editions (See-ton). In the case of multiple-text plays such as Hamlet, King Lear, Henry V and Richard II appropriation of original playtexts is important for at least two reasons. First, because "... editorial conflations may not provide satisfactory foundation for productions" Richman, Taylor \& Warren) $)^{12}$. Second, because the revival of quarto and folio versions will generate fresh approaches to the multiple-text plays, approaches that will perhaps mark the 1990s as a particularly distinctive era in Shakespeare theater.

Staging thus uncovers the limitless possibilities of playtexts, although it often enrages purists and even causes a few offended spectators to leave the theater within the first half-hour of performance. Those who can admit experimen-

\footnotetext{
10 STODDFR, J. H. Anocryphal plays in Las Angeles: continued. Shakespeare Quarterly v. 39, p. $232-238,1988$.

11 DESSEN, A. C. Explorine the script: Shakespeare pay-offs in 1987. Shakespeare Quarterly $\because 29$, D. 219.1988.

12 RICHMN, D. Shakespeare on stage, the King Lear Quarto in rehearsal and performance. Shakespoare Quarterly v. 37, p. 374, 1086. For an Authoritative Anthology on King Lear, sec Taylor, $O$. \& Warren. M. The Division of the Kingdoms, Oxford. Oxford Unix. Press, 1983; RPT, 1986.
} 
tation certainly will continue to enjoy and/or to be influenced by Shakespeare's thought-provoking drama.

\section{CRITICAL APPROACHES AND PERFORMANCE- ORIENTED SCHOLARSHIP}

The innovative approaches to Shakespeare in the 1980's have been the same that shaped literary criticism in general during the decade: poststructuralism or deconstruction, semiotics, feminism, marxism, and, to a lesser degree, psychoanalysis. Their development, of course, started long ago, with critics such as Jacques Derrida, Umberto Eco, Roland Barthes, the philosopher Michel Foucault, and Sigmund Freud.

Even though much current scholarship has poststructuralist features, Hawkes believes that "there is, as yet, no body of deconstructive analysis of Shakespeare". ${ }^{13}$ Calderwood's approach to Hamlet stands as a good practical exam-

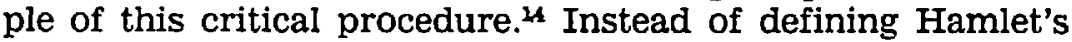
attitude as one of simple delay as the orthodoxy does, Calderwood finds coherence in the play's structure as a negation of traditional revenge tragedy conventions: the protagonist, rather than sweeping to revenge, must determine his own course of action.

The Postructuralist view of text as a malleable object is an improvement over structuralism, ${ }^{15}$ but its sole focus on text has been considered a pitfall, and particularly so in the case of drama, wich is meant to be performed. Ironically, in fact, Shakespeare scholarship practically ignored, well into the 1970's this theatrical dimension and the fundamental distinction between literature and drama, which McGuire \& Samuelson explain with objectivity: ${ }^{16}$

a play is not an artifact but a process, unique with each performance, of making physically present (of realizing) possibilities of perception and feeling that lie attenuated and frozen in the script.

Semiotics, accounting for the complex non-verbal signification of gesture, blocking, costume, make-up, props, scenery, sound effects, etc., provides a much more complete

13 HAWKes, T. Shakespeare and new critical approaches. In WeLLS, S., ed. The Cambridge Companion to Shakespare studies. Cambridge: Cambridge University Press. 1986. p. 293.

14 CALDERWOOD, J. L. To be and not to be: negation and metadrama in 'Mamlet'. Nic York: Columbla Unlversity Press. 1983.

15 Poststructuralists belicve that language cannot be reduced to he type of "Ideal" readings that the structuralists advocated on the basts of stralchtforward word relationships: texts are unfinished objects with unllmitted readablity.

16 MCOURE. P. \& SAMUESON, D. A. Shakespeare, the theatrical dimersion. New York: AMS Press. 1979. D. Xx. 
set of principles than structuralism for dramatic analysis (e. g., Elam. $)^{17}$ Fisch makes a remarkable case for the importance of body language in Shakespeare's plays: he points out that Lady Macbeth's rubbing her hands or King Lear's kneeling, for instance, are not mere parts of stage business, but convey emotions much more eloquently than words would. ${ }^{18}$

In spite of having an essentially structuralist concept of text, semioticians claim that language and meaning are influenced by history and culture not only of the author's period, but of the reader or viewer's as well. Meaning, thus, is best defined as variable effect. In the case of a Shakespearean play, although a script aiways serves as guide, each performance may generate a different effect, both because of what happens on stage and because of the audience's reaction. Wall is an interesting example os this model of analysis that explores plays as verbal, visual and kinesthetic objects. ${ }^{19}$ In a broader sense, several important studies in theater history and audience response are also indebted to semiotics, such as Cook's, Gurr's, Hattaway's Homan et al's and Taylor's. ${ }^{20}$

Semiotic studies have also augmented feminist criticism, since roles determined by gender are another aspect of nonverbal signification. Kehler illustrates this approach in her study of the consequences of love, which reduces women to the status of child, property and animal in The Taming of the Shrew". As Hawkes notes, "to read a Shakespeare text from a woman's point of view involves a radical re-reading of it, against its traditional male-oriented 'grain'.22 In effect, studies such as Parker's, which defines female characters as teleology-braking figures, and Howard's on social order, present rather unorthodox relationships between gender and power. ${ }^{23}$

To claim Marxism is a truly innovative approach would be wrong, since its concepts and phraseology had already

17 ELAM, K. The semiotics of theatre and drama. London: Methuen, 1980.

18 FISCF, II. Shakespeare and the language of gesture. Shakespeare Studies v. 19, p. 239-251, 1987.

19 WALL, C. M. Script, performance, perception: the textual interplay of Coriofannus. Dissertation. University of Colorado. (Dissertation Abstracts International v. 48: 1198A, 1987).

20 COOK, A. The privileged playgoers of Shakespeare's London, 1576-1642. Princeton: Princeton University Press, 1981. GURR. A. Playgoing in Shakespeare's London. Cambridge: Cambridge University Press, 1987. HATTAWAY, M. Elizabethan popular theatre: plays in performarre. London: Routledge and Kegan Paul, 1982. HOMAN S., ed. Shakespeare's more than words can witness. Cranbury: Associated University Presses, 1980. TAYLOR, G. To analyze delight: a hedonist criticism of Shakespeare. Newmark: University of Delaware Press, 1985.

21 KEHLER, D. Fchors of the Induction in The Taming of the Shrew Rena.ssance Papers 1986: p. 31-42.

22 HAWKES, p. 296.

23 PARKER, P. Literary fat ladies: rhetoric, gender, property. London: Methuen, 1987. HOWARD, J. Crossdressing, the theatre, and gender struggle in carly modern England. Shakespeare Quarterly v. 39, p. 418-440, 1988. 
been common by the 1970's (e.g., Weimann). ${ }^{24}$ A different feature of marxist criticism in the 1980's, however, has been the association of ideology and discourse, which finds its origins in Michel Foucault's idea that dominance always involves a verbal contest for power. Shakespearean drama, thus, can be viewed as a kind of battlefield where characters with conflicting discourses try to subordinate each other, be it politically, socially or domestically (e. g., Goldberg.) ${ }^{25}$

Psychoanalysis has provoked much controversy regarding the treatment of characters as real people and probably enjoys the least prestige as a critical approach. Actually, it is Semiotics that appears to have stimulated a revival of psychoanalysis in the 1980s especially as discussions regarding gender and sex grew popular. For the most part, however, these studies have been striking old Freuciian and Jungian tunes of sexuality, idealism and desire, and remain indebted to the ideas of Ernest Jones in the 1940s. In any case, Charney $\&$ Reppen illustrate the range of recent work in this field. ${ }^{26}$ What strikes me as more innovative in psychoanalytic criticism occupies scholars outside of the AngloAmerican picture: dealing with audience response to dramatic effects, or with the extent to which Shakespeare's technique appears to manipulate audience reaction (e. g., Löker; $\mathbf{L i}) . \overline{-}$ I cannot resist remarking that directors are likely to profit from such analyses if, somewhat perversely, they start using them to improve the "marketing" of Shakespeare productions.

The above sketch probably strikes the reader as a com. partment box, since it highlights the reductionist aspect of criticism. As time passes, however, it becomes more and more impracticable to differentiate scholarship. Several intellectual currents began to merge in the $1980 \mathrm{~s}$, producing an eclectization as well as a broadening of reading and inter pretation.

Such fusion is evident in recent anthologies, with essays characterized by an interplay of deconstruction, semiotics, marxism, feminism and psychoanalysis (e.g., Ferguson et

\footnotetext{
24 WEMANN. R. Shakespeare and the popular tradition in the theater. Baltimore: The Johns Hopkins Unlverslty Press. 1978.

25 GOLDBFro. J. James 1 and the politics of literature: Jonson. Shakespeare, Donne, and thoir contemporaries. Baltimore: The Johns Hopkins Unjversity Press. 1983.

26 CHARNEY, M.: REPPEN. J.. ed. Pyychoanalytic approaches to literature and film. Rutherford: Fatrleigh Dickinson Unirergity Press, 1987.

27 LOKFR. A Dreams and psychosynthesis. Istanbul: A. Lcker. 1987. LI. H. "Remarks on the dramatic atmosphere of A Midsummer Night's Dream." Shashibiya yanjiu (Shakespeare Studies) r. 3. p. 197-213. 1986. In Chinese. Even such studjes. however. are somexhat commonplace if we consider that Aristotle already deall with emotional effect when referring to catharsis.
} 
al. ${ }^{28}$ It is even more evident if we try to identify, for example, the current philosophical components of two particularly well-established areas of Shakespeare scholarship, namely, history and textual studies, which have been radically changed.

In history, the cultural-materialist view of Dollimore has simply destroyed E.M.W. Tillyard's classic hierarchy of Elizabethan values. ${ }^{28}$ Dollimore's work is indebted to both poststructuralism (for arriving at a pattern of order through deconstruction) and to Marxism (for relating ideology with discourse). In addition, the body of scholarship called newhistoricism (eg., Greenblatt; Goldberg; Mullaney) clearly employs, though in different styles and degrees, concepts of post-structuralism, semiotics, marxism and feminism in the process of analyzing relatioships between Shakespearean drama and the Elizabethan/Jacobean period. ${ }^{30}$

What motivates this eclecticism appears to be the fact that we've started to question seriously the extent to which the critic's or historian's own historical context and methods limit their perception of an objetc. Dealing with this issue requires, first, accepting its complexity and, second, broadening (rather than narrowing) our interpretative strategies. Such broadening also became essential for studies of the multiple-text plays, with two major trends and notable consequences for editing.

First, revisionist theories were advanced by Warren and by Urkowitz. ${ }^{31}$. In sum, Warren and Urkowitz claimed that we must determine authorial intentions by examining the dramatic coherence of original playtexts, and not simply by making conjectures about composition and printing history. Turning back to quarto and folio versions of Shakespeare's plays, especially King Lear, Warren and Urkowitz demonstrated that many of the textual variations in them are dramatically coherent and appear to be revisions intended by Shakespeare himself, rather than changes made by pirates

28 FERGUBON, M. W.: QULLIGAN, M.: VICKERg, N. J. Rowriting the Ronaissance: tho discourses of sexual difference in early modern Europe. Chfcago: Unlversity of Chicago Prcss, 1988.

29 DOLLIMORE.J. Radical tragedy: religion, ideology, and powor in the drama of Shakespeare and his contomporaries. Chicaco: University of Chlcaco Press, 1984.

30 OREENBLATT, 8. Renaissance self-fashioning from More to Shakespeare. Chlcaro: Unlversity of Chlcago Press, 1980. GOLDBERG, J. James I ... MULLANEY, 8. The place of the stage: license, play, and power in Reraissance England. Chlcago: Universltsy of Chicato Press. 1988.

31 WARREN, M. Quarto and follo Kimg Lear and the interpretation of Edgar and Albany. In BEVINGTON. D. \& HALIO. J. L., ed. Shakespoare: pattern of excolling nature. Newark: University of Delaware Press, 1978, p. 95-107. URKOWITZ. 8. Shakespeare's revision of 'King Loar'. Princeton: Princeton Unlversity Press, 1980. 
or by printers and compositors (as it was traditionally believed).

The revisionists have challenged an "essentially impressionistic editorial orthodoxy" (Urkowitz), 32 which alters Shakespeare by conflating the various versions of nis multipletext plays without accouting for their dramatic art.33 As a result, we have gained, for example, new Henry $V$ and King Lear editions, both with choices and notes that reflect the revisionist method. Of course, these reformers have been severely attacked (e.g., Muir), both as a result of claiming that conflated playtexts are illegitimate, and of indirectly unsettling centuries of scholarship ${ }^{34}$

A second trend in contemporary textual studies can be called true-reformist, including those who, in addition to studying quarto and folio versions, believe that the quest for authorial intentions is pointless, "... since we lack such documents as Shakespeare's various drafts of each play or his notebooks" (McGuire)..$^{35}$ This is not to deny the value of source studies, but simply to take advantage of original playtexts and illuminate interpretation. Other true-reformists, such as Richman, Rauen and Werstine, not only have demons. trated the extent to which modern editions alter the dramatic uniqueness of original scripts, but have also pointed out how radically different effects may emerge from stagings of quarto and folio versions of King Lear, Hamlet, Henry V, and The Merry Wives of Windsor. ${ }^{36}$ This is a fairly well-established area of research, which even begins to spur the publication of special side-by-side facsimile editions (such as The Paralell King Lear, 1608-1623), crucial during close study of variant playtexts. Hopefully, they will also activate the pu. blication of prompt-books and of commentaries by players

32 URKOWITZ. S. "Well-sayd olde Molo - Burying three Hamlets in modern editions. In FURNESS \& ZIEGLER. 1986. p. 37-70.

33 Modern editors since the elghteenth century assumed that. because shakespeare's oricinals are lost. the solution for dealine with the problem that different versions of some of his plays exist was to make assertions about the genesis of the varlants and to merke playtexts, thus recosering the author's intentions and determinine the "bad" versions. The revisionists have argied that when a dramatic text is regularized accordine to criteria better sulted to purcly literary works. such as the Bible. patterns of theatrical cueine embedded in the dialoque are crossls distorted.

34 MUIR. K. Shakespeare: contrasts and controversies. Nerman: Unfrersits of Oklahoms Press. 1985. The rork of revisionists or reformers represents a problem for conservatlve scholarshlp such as Mulr's principally because whatever has been thought written and published about multiple-text plays for over two-hundred years uas based on conflated editions and may, therefore, have to be reevaluated.

25 Mcoulpe. P. Soeelchiess dialet. Berkeley: University of Californta Press. 1965. p. xxil.

36 RichMan. D. Shakespeare on stage. the King Lear quarto in rehearsal and per. formnnce. Shakespeare Quarterly $\vee$. 37. p. 374-382, 1986. RAUEN. M. a. Shakespeare's erdings and effects; a study of quarto and folio versions of The Merry Wives of Windsor, Henry $v$ and Hamlet. Doctoral Dissertatlon: Michigan Etate Unlversity. 1087. WERSTINE. P. The textual mistery of Hamlet. Shakespeare Qunrtcrly *. 39. p. 1-26. 1088. 
of Shakespeare, although we've already gained some in this sense (e.g. Brockbank; Jackson \& Smallwood; Evans.) ${ }^{37}$

Such performance-oriented scholarship is clearly indetebted to various critical approaches. It is a poststructuralist mindset that enables the reformists to perceive text as a dynamic object and to uncover metadramatic relationships. It is semiotics that allows them to explore the playtext as a continuum of language, interpretation and performance. Marxism, feminism, and psychoanalysis, in addition, provide frameworks for the discotery of complex socio-political and emotional significations.

\section{SOME ADDITIONAL CONSIDERATIONS}

The above developments not only have strenghtened the bond between the academy and the theatre, and challenged editorial orthodoxy, but have also had a classroom impact.

In light of contemporary scholarship and criticism, teaching Shakespeare today involves, or at least should involve, much more than reading and discussing modern editions or perceiving the plays as Elizabethan/Jacobean classsics with anachronisms and universals regarding the human experience. One of the strongest indications that much has happened in the lecture hall is a Summer 1990 issue of the Shakespeare Quarterly solely devoted to teaching, after the first two such volumes of 1974 of 1984 .

Innovative teaching entails, first of all, the viewing of productions and, secondly, the comparative study of playtext and performance. Exposure to quarto and folio versions of multiple-text plays and the appraisal of their different dramatic effects would also be a suplemental practice. In short, students are urged to explore dramatic instability, to enjoy openness and to appreciate complexity in terms of theatrical effects. This may also mean learning about Shakespeare's language and technique by performing moments of his plays, in addition to analyzing word relatioships. Enlightening materials are already available, such as a Folger Shakespeare Library videotape on new approaches to teaching Shakespeare, or the $\mathrm{BBC}$ videotapes.

37 BROCKBANK. F., ed. Players of Shakespeare I. New York. Cambridge University Press, 1988. JACKSON. R. \& EMALLWOOD, R., ed. Players of Shakespeare 2. New York: Cambridre University Press, 1988. EVANS, G. B., ed. The Smock Alley 'A Midsummer Night's Droam. Shakespearean prompt-books of the seventeenth century, vol. VII, Charlottesvllle: Unlversity of Virginla Press. 1989. The testimony of actors and altresses, as well as the study of prompt-books, are important for research because they provide Insight on the theatrical realization and posslbilities of pluytexts. 
The study of secondary sources, likewise, is increasingly marked by a non-fundamentalist, openminded philosophy, particularly in the case of the multiple-text plays and in light of reformist scholarship. The name of the game appears to be "start experimenting", drawing freely on current models of interpretation, aiming at a methodological synthesis rather than at patronage.

\section{BIBLIOGRAPHY}

BERKOWITZ, G.M. "Shakespeare in London, January-July 1987." Shakespeare Quarterly v.38, p.495-500, 1987.

- "Shakespeare at the 1988 Edinburgh Festival". Shakespeare Quarterly v.40, p.75-83, 1989.

BROCKBANK, P., ed. Players of Shakespeare I. New York: Cambridge University Press, 1988.

CALDERWOOD, J.L. To be and not to he: negation and metadrama in "Hamlet". New York: Columbia University Press, 1983.

CHARNEY, M. \& REPPEN, J., ed. Psychoanalytic approaches to literature and film. Rutherford: Fairleigh Dickinson University Press, 1987.

COOK, A. The privileged playgoers of Shakespeare's London, 1576-1642. Princeton: Princeton University Press, 1981.

DESSEN, A.C. "Exploring the script: Shakespearean pay-offs in 1987." Shakespeare Quarterly v.39, p.217-226, 1988.

DOLLIMORE, J. Radical tragedy: religion, ideology, and power in the drama of Shakespeare and his contemporaries.

Chicago: University of Chicago Press, 1984.

DRAKAKIS, J., ed. Alternative Shakespeares. London: Methuen, 1985. ELAM, K. The semiotics of theatre and drama. London: Methuen, 1980.

- ed. Shakespeare today: directions and methods of research. Firenze: La Casa Usher, 1984.

EVANS, G. B., ed. The Smock Alley A Midsummer Night's Dream. Shakespearean prompt-books of the seventeenth century, vol. VII. Charlottesville: University of Virginia Press, 1989.

FERGUSON, M.W.; QUILLIGAN, M.; VICKERS, N.J. Rewriting the

Renaissance: the discourses of sexual difference in early modern

Europe. Chicago, University of Chicago Press, 1986.

FISCH, H. "Shakespeare and the language of gesture." Shakespeare Studies v.19, p.239-251, 1987.

FURNESS, H.H. \& ZIEGLER, G., eds. Shakespeare study today. New York: AMS Press, 1986.

GOLDBERG, J. James I and the politics of literature: Jonson, Shakespeare, Donne, and their contemporaries. Baltimore: The Johns Hopkins University Press, 1983. 
GREENBLATT, S. Renaissance self-fashioning from More to Shakespeare. Chicago: University of Chicago Press, 1980.

GURR, A. Playgoing in Shakespeare's London. Cambridge: Cambridge University Press, 1987.

HATTAWAY, M. Elizabethan popular theatre: plays in performance. London: Routledge and Kegan Paul, 1982.

HAWKES, T. "Shakespeare and new critical approaches." In WELLS, S., ed. The Cambridge Companion to Shakespeare Studies. Cambridge: University Press, 1986, p. 287-302.

HOMAN, S. ed. Shakespeare's more than words can witness. Cranbury: Associated University Presses, 1980.

HOWARD, J. "Crossdressing, the theatre, and gender struggle in early modern England." Shakespeare Quarterly v.39, p.418-440, 1988.

JACKSON, MacD. P. "The Wars of the Roses, the English Shakespeare Company on tour." Shakespeare Quarterly v.40, p.208-212, 1989.

JACKSON, R.; SMALLWOOD, R., ed. Players of Shakespeare 2. New York, Cambridge University Press, 1988.

KEHLER, D. "Echoes of the induction in The Taming of the Shrew. Renaissance Papers 1986. p.31-42.

LI, H. "Remarks on the dramatic atmosphere of A Midsummer Night's Dream." Shashibiya yanjiu (Shakespeare Studies) v.3, p.197-213, 1986.

LOKEER, A. Dreams and psychosynthesis. Istanbul: A. Löker, 1987.

McGUIRE, P.C.; SAMUELSON, D. A. Shakespeare: the theatrical di. mension. New York: AMS Press, 1979.

McGUIRE, P. Speechless dialect. Berkeley: University of California Press, 1985.

MUIR, K. Shakespeare: contrasts and controversies. Norman: Univer. sity of Oklahoma Press, 1985.

MULLANEY, $S$. The place of the stage: license, play, and power in Renalssance England. Chicago: University of Chicago Press, 1988.

PARKER, P. Literary fat ladies: rhetoric, gender, property. London: Methuen, 1987.

RAUEN, M.G. “Shakespeare's endings and effects: a study of quarto and folio versions of The Merry Wives of Windsor, Henry $V$ and Hamlet." Doctoral dissertation, Michigan State University, 1987. RICHMAN, D. "Shakespeare on stage, the 'King Lear' Quarto in Rehearsal and Performance." Shakespeare Quarterly v.37, p.374-382, 1986.

SHAKESPEARE, W. Henry v. The Oxford Shakespeare. Ed. TAYLOR, G. Oxford: Clarendon Press, 1982.

—. King Lear. (The complete King Lear, 1608-1623). Ed. WARREN, M. Berkeley: University of California Press, 1988.

- King Lear. (The parallel King Lear, 1608-1623). Ed. WARREN, M. Berkeley: University of California Press, 1988.

SMALLWOOD, R. "Shakespeare at Stratford-upon-Avon, 1988." Shakespeare Quarterly v.40, p.83-94, 1989. 
STODDER, J.H. "Apocryphal plays in Los Angeles: continued." Shakespeare Quarterly v.39, p.232.238, 1988.

TAYLOR, G. To analyze delight: a hedonist criticism of Shakespeare. Newark: University of Delaware Press, 1985.

TAYLOR, G. \& WARREN, M. The Division of the Kingdoms. Oxford: Oxford Univ. Press, 1983; Reprinted 1986.

URKOWITZ, S. Shakespeare's revision of King Lear. Princeton: Princeton University Press, 1980.

- _. "Well-sayd olde Mole' - Burying three Hamlets in modern editions." In FURNESS; ZIEGLER, ed. Shakespeare study today, 1986, p.37-70.

WALL, C.M. "Script, performance, perception: the textual interplay of Coriolanus." Dissertation, University of Colorado. (Dissertation Abstracts International 48:1198A, 1987).

WARREN, M. "Quarto and folio 'King Lear' and the interpretation of Edgar and Albany." In BEVINGTON, D. \& HALIO, JL., ed. Shakespeare: pattern of excelling nature. Newark: University of Delaware Press, 1978, p.95-107.

WATERMEIER, DJ. "Shakespeare in Canada: the 1987 Stratford Festival." "Shakespeare Quarterly v.39, p.226-232, 1988.

WEIMANN, R. Shakespeare and the popular tradition in the theater. Baltimore: The Johns Hopkins University Press, 1978.

WEISS, A. "The Edinburgh Festival, 1987." Shakespeare Quarterly v.39, p.79-89, 1988.

WERSTINE, P. "The textual mistery of Hamlet." Shakespeare Quar. terly v.39, p.1-26, 1988 . 